\title{
Aglomerasi Industri Kelautan melalui Penataan Zonasi Kawasan Strategis Nasional Bima dan Sumbawa Andalan
}

\section{Marine Industry Agglomeration through Zoning Arrangement of the National Strategic Areas of Bima and Sumbawa Mainstay}

\author{
Sitti Hilyana ${ }^{1 *}$, Soraya Gigentika ${ }^{1}$, Endiena Bulan Mutiara Sani ${ }^{2}$, Ummu Kultsum $^{2}$ \\ ${ }^{1}$ Marine Science Study Program, Faculty of Agriculture, Universitas Mataram, Mataram 83115, \\ Indonesia \\ ${ }^{2}$ Directorate of Marine Spatial Planning, Ministry of Marine Affairs and Fisheries of the Republic of \\ Indonesia
}

*Corresponding Author Email: sittihilyana@unram.ac.id

Manuscript received: 04-09-2020. Accepted: 27-10-2021

\begin{abstract}
ABSTRAK
Kawasan Strategis Teluk Bima dan Teluk Saleh Pulau Sumbawa memiliki sumberdaya alam yang yang potensial bagi pengembangan ekonomi kawasan. Melalui penetapan Kawasan Teluk Bima dan Teluk Saleh sebagai Kawasan Strategis Nasional diharapkan pertumbuhan ekonomi di kawasan ini berkembang secara signifikan, sehingga dibutuhkan regulasi dari aspek perencanaan, pemanfaatan dan pengendalian ruang untuk menunjang berbagai kegiatan infrastuktur serta kegiatan sektor lainnya dalam rangka perwujudan ruang yang aman, nyaman, produktif dan berkelanjutan. Penelitian bertujuan untuk menganalisis kesesuaian ruang sebagai kawasan strategis nasional. Pengumpulan data dilakukan melalui studi pustaka dan penelusuran data dan informasi pada istitusi terkait dengan pendekatan FGD. Analisis kesesuaian ruang menggunakan pendekatan Sistem Informasi Geografis (SIG). Hasil penelitian menunjukkan bahwa kawasan Teluk Bima - Teluk Saleh (disebut Bima dan Sumbawa Andalan) layak sebagai kawasan strategis nasional, dengan sektor unggulan pariwisata, industri dan perikanan, sehingga penyusunan Tata Ruang kawasan Strategis penting dilakukan.
\end{abstract}

Kata kunci: kelautan; zonasi; strategis

\footnotetext{
ABSTRACT

The Strategic Areas of Teluk Bima and Teluk Saleh on Sumbawa Island have potential natural resources for regional economic development. Through the determination of the Teluk Bima and Teluk Saleh areas as National Strategic Areas, it is expected that economic growth in this region will develop significantly, so that regulations are needed from the aspects of planning, utilization and control of space to support various infrastructure activities and other sector activities in the context of realizing a safe, comfortable space, productive and sustainable. This study aims to analyze the suitability of space as a national strategic area. Data was collected through library research and searching for data and information on institutions related to the FGD approach. Space suitability analysis using Geographic
} 
Information System (GIS) approach. The results show that the Teluk Bima Bay and Teluk Saleh area (called Bima and Sumbawa Andalan) is worthy of being a national strategic area, with the leading sectors of tourism, industry and fisheries, so that it is important to prepare the Spatial Planning of the Strategic area.

Keywords: marine; zoning; strategic

\section{PENDAHULUAN}

Kawasan Strategis Nasional (KSN) adalah wilayah yang penataan ruangnya diprioritaskan karena mempunyai pengaruh sangat penting secara nasional terhadap kedaulatan negara, pertahanan dan keamanan negara, ekonomi, sosial, budaya, dan/atau lingkungan, termasuk wilayah yang telah ditetapkan sebagai warisan dunia. Rencana Zonasi Kawasan Strategis Nasional (RZ KSN) merupakan rencana yang disusun untuk menentukan arahan pemanfaatan ruang kawasan strategis nasional. Hal ini tertuang dalam Perpres Nomor 18 tahun 2020 bahwa pencapaian sasaran pokok pembangunan nasional khususnya terkait Penguatan Ketahanan Ekonomi untuk Pertumbuhan Berkualitas, Pembangunan Lingkungan Hidup, Peningkatan Ketahanan Bencana dan Perubahan Iklim dan Penguatan Stabilitas Polhukam dan Transformasi Pelayanan Publik.

Kawasan Bima dan sekitarnya termasuk Teluk Saleh merupakan salah satu kawasan strategis nasional dan kawasan andalan yang tercantum dalam Peraturan Pemerintah No 13 tahun 2017 tentang Rencana Tata Ruang Wilayah Nasional. Penetapan kawasan Bima dan Sumbawa sebagai KSN karena memiliki peran besar bagi aglomerasi kelautan yang mampu menggerakkan ekonomi nasional dan perlindungan keanekaragaman hayati. Pengembangan kawasan yang merupakan aglomerasi kekayaan alam dan sosial budaya di Kota Bima, Kabupaten Bima, Dompu dan Kabupaten Sumbawa dijadikan sebagai dasar pengelolaan kawasan pesisir dan laut sebagai bagian dari Pengelolaan Kawasan Pesisir Secara Terpadu (Integrated Coastal Zone Management/ ICZM).

Untuk melindungi sumberdaya alam dan lingkungan perairan laut, serta pemanfaatan potensi sumberdaya perairan di kawasan Bima dan Sumbawa, sesuai amanat UU 32/2014 tentang Kelautan, serta arahan kebijakan maritim dan kelautan sebagaimana tercantum dalam RPJMN 2015-2019, perlu dilakukan analisis kesesuaian penetapan kawasan Bima -Sumbawa Andalan sebagai kawasan strategis nasional.

\section{BAHAN DAN METODE}

Penelitian dilaksanakan pada bulan Mei sampai dengan September 2020. Pengumpulan data sekunder dari berbagai sumber yang relevan, dipilih secara terstruktur dari instansi terkait. Data sosial ekonomi menggunakan metode survei dan FGD. Analisis penetapan rencana zonasi menggunakan Analisis tumpang susun melalui overlay potensi pemanfaatan ruang laut untuk menghasilkan kesesuaian peruntukan laut dilanjutkan dengan harmonisasi alokasi pemanfaatan ruang laut melalui overlay pemanfaatan eksisiting ruang laut sehingga menghasilkan keragaman dan intensitas pemanfaatan ruang laut dengan bantuan GIS menggunakan software Arc Gis ver.9. 


\section{HASIL DAN PEMBAHASAN}

Kota dan Kabupaten Bima serta kawasan sekitarnya seperti Dompu dan Kabupaten Sumbawa merupakan kesatuan kawasan di Pulau Sumbawa yang memiliki potensi dan nilai strategis. Letak Bima yang berada di diantara ikon wisata unggulan Indonesia bahkan destinasi wisatawan mancanegara seperti Bali, Lombok dan komodo dapat dilihat sebagai posisi yang sangat strategis sebagai destinasi wisata yang terintegrasi dengan wisata Sumbawa.

Kawasan Bima dan Sumbawa memiliki sektor dengan status cepat tumbuh seperti Perikanan, Pertanian, Pariwisata . Sektor perikanan dan pariwisata merupakan sektor unggulan penggerak pertumbuhan ekonomi nasional.

Wilayah Kota Bima secara umum dilalui oleh dua sungai, yaitu Sungai Lampe yang melintasi wilayah Kecamatan RasanaE Timur. Sungai kedua merupakan terusan dari Sungai Lampe yaitu Sungai Salo yang melewati Penatoi dan terus mengalir melewati Sungai Padolo dan bermuara ke Teluk Bima. Sungai-sungai lainnya yang ada di Kota Bima antara lain Sungai Melayu, Sungai Lewi Jambu dan Sungai Romo yang melewati Kelurahan Melayu dan terdapat sungai-sungai kecil lainnya yang merupakan anak sungai dari dua sungai besar yang telah disebutkan diatas. Untuk Sumber air lainnya yang digunakan untuk kebutuhan penduduk berasal dari sumur dengan kedalaman tiap sumur berbeda-beda sesuai dengan lokasi dan ketinggian permukaan tanah di wilayah Kota Bima.

Kecamatan Rasanae Barat dilalui 2 Sungai yaitu sungai Padolo dan sungai Romo. Sungai terbesar dan juga merupakan drainase primer Rasanae Barat adalah sungai Padolo yang merupakan batas kelurahan Dara dengan Paruga dan sungai Romo yang melintasi Kelurahan Sarae dan merupakan batas Kelurahan Sarae dengan Kelurahan Melayu. Hal ini menyebabkan Kecamatan Rasanae Barat memiliki potensi air permukaan yang cukup baik untuk kegiatan rumah tangga maupun irigasi.

Berdasarkan Jenis tanah, kawasan pesisir Bima terdiri dari alluvial hidromorf dengan luas sekitar 33,94\% dari keseluruhan luas wilayah Kecamatan Rasanae Barat namun secara umum Berdasarkan kelasnya, tekstur tanah di wilayah Kota Bima dibedakan menjadi tekstur tanah halus sampai dengan tekstur tanah kasar. Tekstur tanah halus mencakup hampir $65,90 \%$ dari seluruh wilayah sedangkan tekstur tanah kasar mencakup 3,09\% dari seluruh wilayah Kota Bima.

Sebagian besar keelerengan tanah berada pada $0-2 \%$ dan ketinggian $0-4 \mathrm{~m}$ diatas permukaan laut. Kondisi kelerengan tanah tersebut berdampak pada aliran air hujan yang mengalami hambatan, sehingga akan terjadi kantong-kantong air atau genangan-genangan air hujan, sehingga air hujan tidak sampai ke laut. Kondisi ini dikarenakan perbedaan tinggi tempat yang sangat kecil dan kecepatan aliran air tidak mencapai titik nol. Pada kondisi demikian, air laut justru masuk ke daratan terutama pada waktu air laut pasang.Oleh karena itu di wilayah ini terdapat daerah transisi berupa air payau.Daerah ini dimanfaatkan oleh penduduk untuk kegiatan tambak budidaya bandeng maupun udang.

Saat ini sudah terdapat industri dan budidaya minapolitan rumput laut; budidaya air payau seperti ikan bandeng dan tambak udang, budidaya kakap dan tambak Garam. Untuk perikanan tangkap, udang dan ikan tuna merupakan produk unggulan yang memberikan kontribusi terhadap perikanan nasional. Sedangkan Garam di teluk saleh merupakan salah satu penyumbang garam di Provinsi NTB.

Teluk Saleh yang berbatasan dengan Kabupaten Dompu dan Kabupaten Sumbawa merupakan daerah esensial bagi kehidupan laut. Hamparan terumbu karang seluas $31.565 \mathrm{Ha}$ (41,3\% dari luas terumbu karang Provinsi NTB). Ekosistem lamun seluas $3.460 \mathrm{Ha}$ dan ekosistem mangrove seluas 2.736 ha, serta biota laut (DKP NTB, 2016) yang saling terkait 
membentuk fungsi ekologi sehingga Teluk Saleh, Pulau Moyo dan Tambora ditetapkan sebagai Cagar Biosferoleh UNESCO pada 19 Juni 2019 di Paris, Perancis. Penetapan Samota sebagai cagar biosfer dunia dinilai bermanfaat untuk konservasi sumber daya alam dan pembangunan kesejahteraan sosial dan ekonomi, dengan mengacu prinsip-prinsip pembangunan berkelanjutan yang mengintegrasikan kekayaan sumber daya kelautan, pariwisata, gunung, pertanian dan peternakan, maupun geowisata.

Selain itu terdapat Cagar alam seluas 23.840,81 Ha dan Suaka Margasatwa seluas \pm 11.670 ha dan Taman Buru seluas $\pm 26.130,15$ ha (Dinas LHK, 2019). Pulau pulau di sekitar Teluk Saleh dan kawasan Bima juga menjadi lokasi perlindungan keanekaragaman hayati seperti di Gili Banta dan P. Sangiang; sedangkan kawasan perlindungan keseimbangan tata guna air yang berpeluang menimbulkan banjir yaitu Kawasan Hutan Kapenta; dan Perlindungan keseimbangan iklim makro, rawan bencana alam dan berdampak terhadap kelangsungan kehidupan.

Potensi wisata alam didukung oleh budaya dan adat di Desa adat Mbawa Kec. Donggo, Desa adat Sambori Kec. Lambitu, Maria Kec. Wawo dan Oi Bura Kec.Tambo merupakan factor pendukung keindahan alam kawasan Teluk Saleh dan Kawasan Bima. Nilai keindahan bentang alam bawah laut dan landscape perbukitan serta nilai sosial budaya sebagai daya tarik wisata, didukung jaringan prasarana dan fasilitas penunjang kegiatan ekonomi dan jasa kelautan menjadi peluang pengembangan yang sangat potensial bagi pusat pertumbuhan ekonomi wilayah.

\section{Rencana Alokasi Ruang}

Rencana alokasi ruang RZ KSN Bima dan Sumbawa Andalan ditetapkan sebagai hasil analisis tiga dimensi ruang, yaitu permukaan, kolom, dan dasar laut. Pada setiap dimensi, alokasi ruang laut diakomodir berbagai pemanfaatan yang bersifat multifungsi pada zona tertentu. Dalam kolom perairan pesisir dan pulau-pulau kecil secara vertikal dapat dialokasikan untuk berbagai zona/subzona peruntukan. Alokasi pemanfaatan ruang ditetapkan berdasarkan hasil analisis peruntukan ruang laut secara vertikal. Alokasi berbagai zona/subzona dilengkapi dengan aturan pemanfaatan ruang yang memuat aturan kegiatan yang diperbolehkan dan tidak diperbolehkan, serta kegiatan yang hanya boleh dilakukan dengan persyaratan pengaturan waktu tertentu.

Rencana pola ruang di alokasikan kedalam Kawasan Pemanfaatan Umum, Kawasan Konservasi, dan Kawasan Strategis Nasional Tertentu dan Alur Laut, yang dijabarkan ke dalam penataan zona dan arahan pemanfaatan setiap zona terhadap ruang yang memiliki nilai penting dan strategis untuk kepentingan nasional. Berdasarkan hasil analisis kesesuaian dan dengan memperhatikan keberadaan Objek Vital Nasional/ keberadaan Proyek Strategis Nasional, rencana alokasi ruang di Kawasan Strategis Nasional (KSN) Bima dan Sumbawa Andalan, terdiri atas :

\section{Struktur Ruang Laut}

Rencana struktur ruang laut KSN Bima-Sumbawa Andalan, terdiri atas sistem pusat pertumbuhan kelautan dan perikanan, dan sistem jaringan sarana prasarana kelautan dan perikanan sesuai arahan perencanaan ruang laut sebagaimana tertuang dalam Pengelolan Ruang Laut dan Rencana Tata Ruang laut Nasional (RTRLN).

Rencana struktur ruang laut RZ KSN di Kawasan Bima-Sumbawa Andalan terdiri atas:

a. Susunan pusat pertumbuhan kelautan; dan

b. Sistem jaringan prasarana dan sarana laut. 


\section{Pusat Pertumbuhan Kelautan dan Perikanan}

Susunan pusat pertumbuhan meliputi pusat pertumbuhan kelautan dan perikanan yang berperan sebagai sentra produksi bahan baku, sentra pengumpul, pengolahan, dan distribusi terdiri atas:

a. Sentra usaha garam di Kabupaten Sumbawa, Kabupaten Bima dan Kota Bima.

b. Sentra perikanan tangkap dan/atau perikanan budidaya berada di Kabupaten Sumbawa, Kabupaten Dompu, dan Kota Bima.

Tabel 1. Fungsi Kawasan Kota Bima Menurut Rencana Tata Ruang Wilayah Tahun 2019

\begin{tabular}{|l|l|l|l|}
\hline \multicolumn{1}{|c|}{ Fungsi } & \multicolumn{1}{|c|}{ Lokasi } & \multicolumn{1}{c|}{$\begin{array}{c}\text { Kegiatan } \\
\text { Utama }\end{array}$} & \multicolumn{1}{c|}{ Peran dan fungsi } \\
\hline $\begin{array}{l}\text { Kecamatan } \\
\text { Rasanae Barat } \\
\text { sebagai }\end{array}$ & $\begin{array}{l}\text { Bima dan } \\
\text { sekitarnya: }\end{array}$ & $\begin{array}{c}\text { Perdagangan } \\
\text { dan jasa }\end{array}$ & - Pusat pengembangan perdagangan \\
Pusat Pelayanan & Kelurahan jasa skala nasional dan regional \\
Kota & Tanjung, & & - Simpul transportasi darat dan laut \\
& Kelurahan Dara, & & Skala nasional dan regional \\
& Kelurahan arae, & & - Daerah tujuan wisata budaya dan \\
& Kelurahan Paruga & & bahari \\
\hline
\end{tabular}

Sumber: RTRW Kota Bima, 2019

\section{Sistem Jaringan Prasarana dan Sarana Laut}

Sistem jaringan prasarana dan sarana laut berupa pelabuhan, sesuai ketentuan peraturan perundang-undangan. Peta rencana struktur dapat dilihat pada gambar berikut:

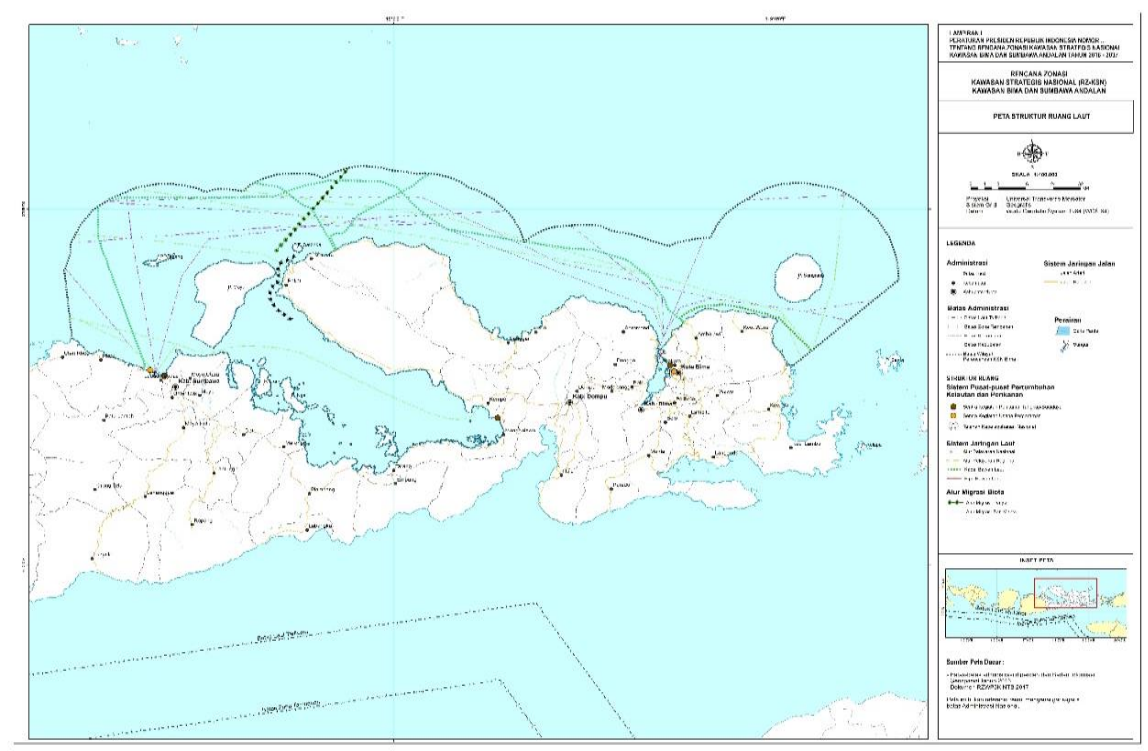

Gambar 1. Peta Rencana Struktur Ruang RZ KSN Bima dan Sumbawa Andalan

\section{Pola Ruang Laut}

Rencana Pola Ruang Laut RZ KSN di Kawasan Bima dan Sumbawa Andalan terdiri atas : Kawasan Pemanfaatan Umum; Kawasan Konservasi; dan Alur Laut. 


\section{Kawasan Pemanfaatan Umum \\ Zona Pelabuhan}

Secara ekonomi, pelabuhan berfungsi sebagai salah satu penggerak roda perekonomian karena merupakan fasilitas yang memudahkan distribusi hasil produksi sedangkan secara social, pelabuhan menjadi fasilitas publik yang berlangsung interaksi antar pengguna termasuk interaksi yang terjadi karena aktivitas perekonomian.

Berdasarkan hasil penelusuran lapang, bahwa penggunaan pelabuhan di kawasan strategis nasional Bima dan Sumbawa andalan memudahkan produksi hasil pertanian seperti jagung dari sentra produksi di daeran Casey, Kempo dan Pekat, produk perkebunan seperti gula dari Doropeti dan Pekat, sedangkan produk perikanan yang bersumber dari Pekat, Narngamiro, Labuan Kenanga dan beberapa daerah sekitar yang menjadi sentra perikanan tangkap.

DLKr terbagi atas DLKr wilayah daratan dan DLKr wilayah perairan. DLKr daratan mencukup fasilitas pokok serta fasilitas penunjang. Fasilitas pokok yang dimaksud seperti di antaranya, dermaga, tentunya termasuk coast-way dan trestle yang menghubungkan dermaga dengan daratan. Fasilitas lainnya berupa tempat penyimpanan barang, seperti gudang, lapangan penumpukan, terminal peti kemas serta terminal curah cair/kering. Fasilitas penunjang DLKr daratan, antara lain, kawasan perkantoran, instalasi air bersih/listrik/telekomunikasi, jaringan jalan, jaringan air limbah/ drainase, kawasan perdagangan serta kawasan industri.

DLKr perairan dimanfaatkan untuk alur pelayaran dari dan menuju pelabuhan; tempat kapal berlabuh; lokasi alih muat antar kapal (ship to ship transhipment); kolam pelabuhan untuk kapal bersandar, kolam pelabuhan untuk areal olah gerak kapal (kebutuhan areal untuk kapal berputar arah); kegiatan karantina serta kapal pemerintah. Daerah lingkungan kepentingan pelabuhan digunakan untuk kegiatan, keperluan keadaan darurat (seperti kapal terbakar atau kapal bocor); penempatan kapal mati; percobaan kapal berlayar; kegiatan pemanduan kapal serta fasilitas perbaikan/pemeliharaan kapal.

\section{Zona Pariwisata}

Zona Pariwisata di Kabupaten Sumbawa, terletak perairan Pulau Moyo, sebagian merupakan kawasan konservasi, dengan arahan pengembangan wisata bahari; pengembangan objek-objek yang dapat menjadi magnet wisata; konektivitas zona pariwisata dengan pusat kegiatan lainnya; pengembangan nonfisik seperti alternatif paket wisata Pulau Moyo, Pulau Satonda dan perairan sekitarnya, maupun dengan magnet wisata sekitar di Pulau Sumbawa; penyedian sarana prasarana penunjang wisata tanpa mengganggu ekosistem; serta pengembangan sarana komersial sekaligus sebagai sarana pemasaran hasil usaha kelautan dan perikanan di Kabupaten Sumbawa.

\section{Zona Energi}

Zona energi di wilayah pesisir Bima dan Sumbawa Andalan adalah Pembangkit Listrik Tenaga Mesin Gas (PLTMG) di Kecamatan Labuan Badas, Kabupaten Sumbawa, Pembangkit Listrik Tenaga Uap (PLTU) di Kacamatan Plampang, Sumbawa, Pembangkit Listrik Tenaga Mesin Gas dan Pembangkit Listrik Tenaga Uap (PLTU) di Kecamatan Asakota, Kota Bima. Arahan pengembangan zona energi antara lain memastikan bahwa setiap pelaku usaha tetap memperhatikan kelestarian ekosistem sekitar; penerapan metode pengelolaan limbah yang tepat guna, untuk meminimalisir dampak negatif yang terjadi; dan pengembangan kerjasama dalam pengelolaan PLTU/PLTGU antara pemerintah, masyarakat, perusahaan, dan stakeholder lainnya. Membangun sektor pariwisata dan perikanan memerlukan infrastruktur listrik. Pembangunan transmisi saluran udara tegangan tinggi (SUTT) $70 \mathrm{kV}$ untuk mendukung pengembangan kawasan SAMOTA. 


\section{Zona Pertahanan dan Keamanan}

Ruang laut yang dialokasikan untuk kawasan pertahanan dan kemanan di kawasan pesisir Bima dan Sumbawa Andalan mengacu pada PP 68 Tahun 2014 tentang Penataan Wilayah Pertahanan Negara adalah kawasan yang dimanfaatkan bagi pertahanan dan keamanan negara berupa kawasan militer. Lokasi perairan yang digunakan untuk kepentingan militer di kawasan pesisir Bima dan Sumbawa Andalan berupa lokasi ranjau di perairan Teluk Bima.

\section{Kawasan Konservasi}

Kawasan Konservasi pada perairan KSN Bima dan Sumbawa Andalan merupakan kawasan lindung disebut Zona KK-SW, ditetapkan dengan tujuan kelestarian ekosistem pesisir, laut dan Pulau-pulau kecil. Kawasan Konservasi diantaranya adalah Kawasan Konservasi Pulau Moyo berdasarkan SK Menhut No SK.308/KPTS-II/96, dan Pulau Satonda SK Menhut No.22/KPTS-II/98.

\section{Alur Laut}

\section{Alur Pelayaran}

Dalam RZ KSN Bima dan Sumbawa Andalan terdapat Alur Pelayaran Pelayaran Nasional dan Pelayaran Regional.

Pelayaran Nasional merupakan jaringan pelayaran yang menghubungkan pelabuhan nasional dan pelabuhan internasional dalam jumlah menengah, dikembangkan untuk melayani kegiatan pelayaran dan alih muat peti kemas angkutan laut nasional, menjangkau wilayah pelayanan menengah; dan memiliki fungsi sebagai simpul jaringan transportasi laut nasional.

Pelayaran Regional, merupakan alur sistem pelayaran regional yang disesuaikan dengan sistem rute yang biasanya digunakan untuk navigasi regional dan merupakan jaringan pelayaran yang menghubungkan antara pelabuhan pengumpan primer ke pelabuhan utama yang melayani secara nasional, dikembangkan untuk melayani kegiatan pelayaran dan alih muat angkutan laut nasional dan regional, pelayaran rakyat, angkutan sungai, dan angkutan perintis dalam jumlah menengah; dan menjangkau wilayah pelayanan menengah.

Rencana alokasi ruang kawasan alur laut zona alur pelayaran dengan sub zona Pelayaran Nasional dan Pelayaran Regional pada KSN Bima dan Sumbawa Andalan adalah :

a. Alokasi ruang zona alur pelayaran dengan sub zona Pelayaran Nasional, ditetapkan di Perairan Selat Bima Kabupaten Bima dan Kota Bima.

b. Alokasi ruang zona alur pelayaran dengan sub zona Pelayaran Regional, ditetapkan di Perairan Selat Bima Kabupaten Bima dan Kota Bima. Serta perairan Laut Flores pada wilayah Kabupaten Sumbawa.

Dalam implementasi rencana alokasi ruang alur pelayaran dan perlintasan dengan sub zona Pelayaran Nasional, Pelayaran Regional dan Pelayaran Lokal dibutuhkan arahan pengembangan antara lain :

1. Pencegahan pencemaran lingkungan laut dengan tidak melakukan pembuangan Limbah (dumping) diperairan.

2. Mendukung kebijakan pemeliharaan Alur Pelayaran Teluk Bima dan Laut Flores yang merupakan alur pelayaran yang melayani pelayaran rakyat dari Pelabuhan Bima dan Pelabuhan Badas ke pelabuhan-pelabuhan di bagian Timur Indonesia. 
3. Memelihara alur pelayaran guna menjaga keselamatan berlayar, tata ruang perairan dan kelestarian lingkungan

4. Pengidentifikasian dimensi alur pelayaran lokal pada seluruh kabupaten/kota di wilayah pesisir Provinsi Nusa Tenggara Barat

5. Pengidentifikasian penetapan lokasi Sarana Bantu Navigasi Pelayaran (SBNP) untuk melakukan pemantauan terhadap lalu lintas kapal asing yang melalui alur pelayaran di perairan Provinsi Nusa Tenggara Barat.

6. Peningkatan pelayanan angkutan laut di wilayah pelayaran rakyat dengan peraian yang memiliki alur kedalaman terbatas.

\section{Alur Pipa dan Kabel Bawah Laut}

Rencana alokasi ruang pipa dan kabel bawah laut di perairan Bima dan Sumbawa Andalan meliputi Pipa Minyak dan Gas, Kabel Telekomunikasi dan Kabel Listrik. Dalam perencanaan alur pipa dan kabel bawah laut mengikuti kondisi eksisting sebagaimana tertuang pada data alur pipa dan kabel bawah laut dari Pushidros Angkatan Laut (2015) serta data jaringan distribusi pipa migas dari Kementerian Energi dan Sumber Daya Mineral (2010). Alokasi ruang alur pipa dan kabel bawah laut, ditetapkan sebagai berikut :

a. Alokasi ruang pipa minyak dan gas berada di Perairan di Teluk Bima;

b. Alokasi ruang kabel telekomunikasi berada di wilayah utara KSN Bima dan Sumbawa Andalan. Titik pendaratan (landing point) diarahkan pada dua titik, yaitu di Kabupaten Sumbawa dan Kabupaten Bima. Penggelaran kabel dilaksanakan untuk kabel telekomunikasi swasta atau palapa ring.

c. Alokasi ruang kabel listrik diarahkan menuju lokasi-lokasi yang belum terlayani oleh jaringan listrik terutama dipulau-pulau kecil.

\section{Alur Migrasi Biota}

Wilayah perairan KSN Bima dan Sumbawa Andalan merupakan kawasan dengan tingkat keanekaragaman hayati yang tinggi. Keberadaan Teluk Saleh sebagai cagar biosfer dunia, dengan berbagai jenis biota laut yang hidup dan bermigrasi dari dan/atau ke wilayah perairan Teluk Saleh dilindungi menurut undang-undang dan termasuk APENDIX CITES seperti Pari Manta, Penyu (Gong S.P, 2009), Hiu (Cardeñosa D,2018), Bambu Laut, dan lumba-lumba (KKP RI, 2015). Arahan pengembangan disekitar alur migrasi biota antara lain pengendalian kegiatan disekitar alur migrasi seperti labuh jangkar, penangkapan ikan, penggelaran kabel dan pipa bawah laut, kegiatan penambangan, dan pembuangan limbah; serta sosialisasi dan kerjasama pengamanan alur biota laut yang dilindungi.

Peta rencana pola ruang KSN Bima dan Sumbawa Andalan dapat dilihat pada gambar berikut: 


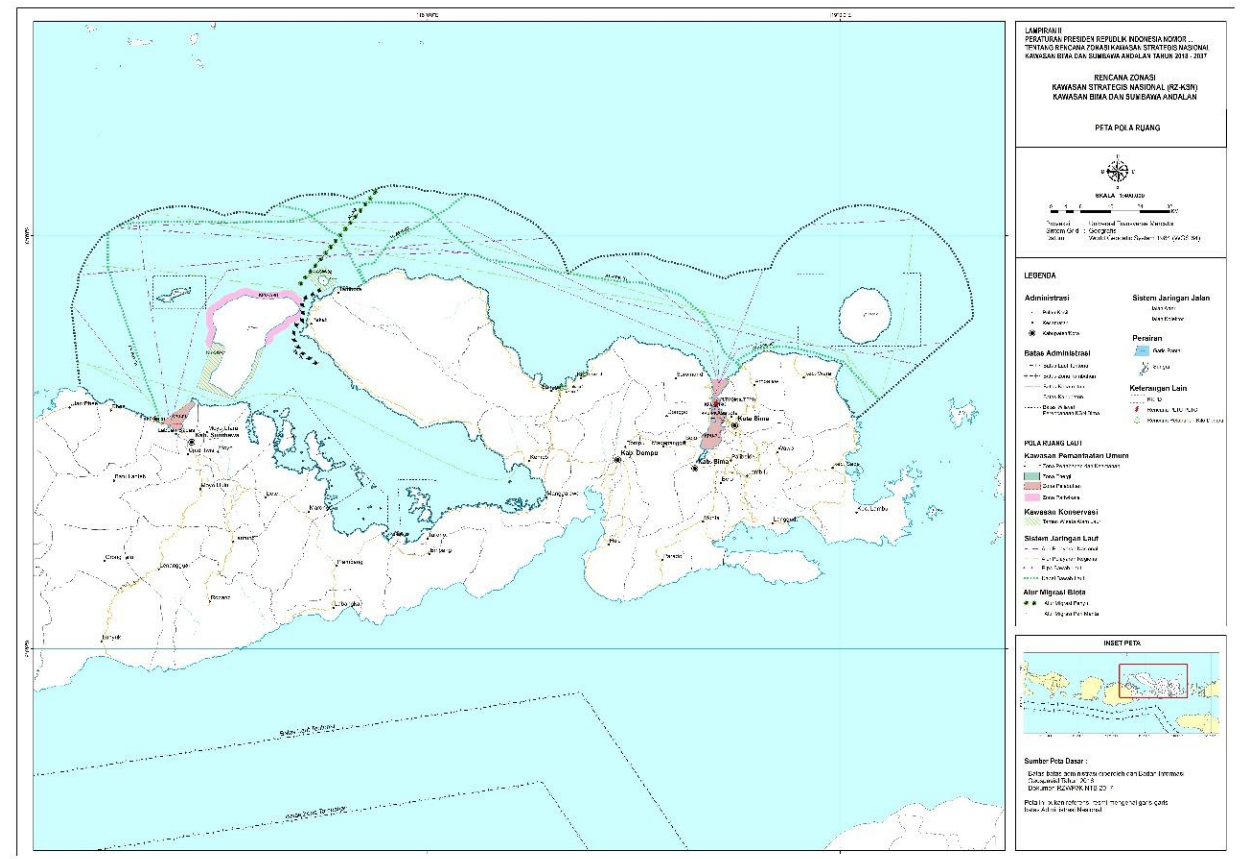

Gambar 2. Peta Rencana Pola Ruang RZ KSN Bima Sumbawa Andalan

\section{KESIMPULAN}

Indikasi program RZ KSN merupakan program-program pengembangan kawasan strategis nasional diutamakan terhadap ruang laut yang memiliki nilai penting dan strategis untuk kepentingan nasional, berdasarkan nilai kepentingan atau prioritas untuk mewujudkan pengelolaan ruang kawasan strategis nasional sesuai tujuan, kebijakan dan strategi dalam jangka waktu perencanaan setiap 5 (lima) tahun hingga 20 (dua puluh) tahun. Indikasi program utama lima tahunan RZ KSN Bima dan Sumbawa Andalan berupa :

\section{Perwujudan Struktur Ruang Laut terdiri dari}

a. Sistem Pusat Pertumbuhan Kelautan dengan arahan pengembangan sebagai sentra kegiatan penggaraman dan pengembangan sentra kegiatan perikanan tangkap dan perikanan budidaya

b. Sistem Jaringan Sarana dan Prasarana Kelautan dengan arahan pengembangan Pelabuhan Bima dan Pengembangan Pelabuhan Badas

2. Perwujudan Pola Ruang Laut terdiri dari:

Kawasan Pemanfaatan Umum berupa pengelolaan persampahan dan pengendalian kegiatan yang mengganggu fungsi zona. Zona pemanfatan umum terdiri atas:

a) Zona Pelabuhan dengan arahan pengembangan dan peningkatan pengelolaan pelabuhan umum, Penataan kegiatan di pesisir zona pelabuhan, Pembersihan daerah ranjau, pendalaman alur dan zona pelabuhan, pengamanan ruang untuk operasional kegiatan pembangkit listrik, mengembangkan akses dan jasa kepelabuhanan dan pengelolaan jalur pelayaran.

b) Zona Pariwisata dengan arahan pengembangan obyek wisata di Pulau Moyo dan sekitarnya, pengembangan konektifitas melalui paket wisata (darat dan laut), penyediaan 
prasarana dan sarana penunjang wisata, menyediakan ruang pengelolaan dan perdagangan hasil kelautan dan perikanan, dan pengembangan tempat sandar, terminal khusus pariwisata, atau Pelabuhan Wisata.

c) Zona Energi dengan arahan pengembangan pengembangan PLTMG, Pengembangan PLTU, dan Pengembangan saranan distribusi air dalam mendukung operasional pembangkit Listrik.

d) Zona Pertahanan dan Keamanan dengan arahan pengembangan Pengembangan wilayah pertahanan keamanan untuk daerah Ranjau

Kawasan Konservasi berupa Penyusunan rencana pengelolaan TWAL, Penertiban aktivitas yang menggangu fungsi TWAL, Penyiapan regulasi tentang aktivitas wisata bahari, Sosialisasi dan peningkatan kapasitas pengelolaan Kawasan Konservasi dan Pengembangan sarana dan prasarana pendukung untuk kegiatan monitoring, konservasi, penelitian dan pengembangan Alur Laut berupa:

a) Alur Pelayaran dengan arahan pengembangan penataan jalur pelayaran umum, Penataan dan pengelolaan jalur transportasi wisata, Pengamanan alur perikanan tradisional dan penyediaan angkutan penumpang, barang dan wisata

b) Alur Pipa Bawah Laut dengan arahan pengembangan menyediakan ruang untuk alur pipa penunjang Depo BBM dan Instalasi pipa minyak dan gas.

c) Alur Kabel Bawah Laut dengan arahan pengembangan Penyediaan ruang untuk kabel telekomunikasi, Penggelaran kabel telekomunikasi, Penggelaran jaringan Pallapa Ring, Penataan titik pendaratan kabel laut dan Pengawasan dan perawatan jalur kabel telekomunikasi bawah laut.

Alur Migrasi Biota berupa Sosialisasi pengamanan alur migrasi biota laut dilindungi dan Pengendalian kegiatan di sekitar alur migrasi biota.

\section{DAFTAR PUSTAKA}

Cardeñosa Diego, Fields Andrew T, Babcock. Elizabeth A, 2018. CITES-listed sharks remain among the top species in the contemporary fin trade. Conservation Letters. DOI: 10.1111/conl.12457

DKP NTB, 2016. Naskah Akademik Rencana Zonasi Wilayah Pesisir dan Pulau-Pulau Kecil Provinsi Nusa Tenggara Barat, 2016. Pemerintah Daerah Provinsi NTB.

Dinas LHK, 2019. Informasi Kinerja Lingkungan Hidup Daerah (IKPLHD NTB 2020). Pemerintah daerah Provinsi NTB.

Dewi Kusuma, 2017. Peran Consevation International (CI) dalam Upaya Melestarikan Ikan Pari Manta di Indonesia. http://eprints.upnyk.ac.id/id/eprint/12272

KKP RI, 2015. Surat Edaran No. SE 526 tahun 2015 tentang Pelaksanaan Perlindungan Penyu, Telur, Bagian Tubuh, dan/atau Produk Turunannya.

Peraturan Presiden (PERPRES) Nomor 18 tahun 2020. Rencana Pembangunan Jangka Menengah Nasional Tahun 2020-2024. Program Rencana Pembangunan dan Rencana Kerja Kebijakan Pemerintah. LN.2020/NO.10, JDIH.SETKAB.GO.ID: 7 HLM. 
Perda Kota Bima Nomor 4 Tahun 2012. Rencana Tata Ruang Wilayah Kota Bima tahun 2011 - 2031. Pemerintah Kota Bima. $126 \mathrm{Hal}$

Perda Kabupaten Bima Nomor 9 Tahun 2011. Rencana Tata Ruang Wilayah Kabupaten Bima tahun 201 - 2031. Pemerintah Kabupaten Bima. 99 Hal

Perda Kabupaten Sumbawa Nomor 10 Tahun 2012. Rencana Tata Ruang Wilayah Kabupaten Bima tahun 2011 - 2031. Pemerintah Kabupaten Sumbawa. 126 Hal

Peraturan Pemerintah (PP) Nomor 7 tahun 1999 tentang Pengawetan Jenis Tumbuhan dan Satwa. Pemerintah Republik Indonesia.

Permen LHK No.20 tahun 2018 tentang jenis dan satwa yang dilindungi.Kementerian Lingkungan Hidup dan Kehutanan Republik Indonesia.

Permen LHK No. 106 tahun 2018 tentang perubahan Permen LHK No.20 tahun 2018 menyatakan bahwa 6 jenis penyu tergolong satwa yang dilindungi oleh UndangUndang. Kementerian Lingkungan Hidup dan Kehutanan Republik Indonesia.

Ping G S, Chow, AT., Fong JJ, 2009. The chelonian trade in the largest pet market in China: scale, scope and impact on turtle conservation. Published online by Cambridge University Press

Rencana Pembangunan Jangka Menengah Nasional 2014-2019. Pemerintah Republik Indonesia.

SK Menhut No SK.308/KPTS-II/96 tentang Penetapan Pulau Moyo sebagai Taman Wisata Alam Laut (TWAL). Kementerian Kehutanan Republik Indonesia.

Soehartono, T. and A. Mardiastuti, 2002. CITES Implementation in Indonesia. Nagao Natural Environment Foundation, Jakarta.

Undang Undang No 5 tahun 1990 tentang Konservasi Sumber Daya Alam Hayati dan Ekosistemnya.

Undang Undang Republik Indonesia Nomor 32 Tahun 2014, tentang Kelautan. Pemerintah Republik Indoensia.

UNESCO, 1996. Bhiophere reserves: The Seville Strategy and the Statutory Framework of the World Network. UNESCO, Paris. 